\title{
The Design of Knitting Dress and the Development Orientation of Knitting Enterprises
}

\author{
Tianpeng Liu \\ College of Art and Appareluages \\ Tianjin Polytechnic University \\ Tianjin 300160, China \\ Tel: 86-22-2641-4423 E-mail: Tianpengliu@yahoo.cn
}

\begin{abstract}
At present, in the fashion domain, the uniform advantage of tatting products have been broken by knitting products which suddenly rise and partly occupy the market, so the situation that knitting products and tatting products occupy the market together begins to form. Because of their own characters of knitting dress or tatting dress, they can not be replaced. But in future, the knitting dress should not isolate itself even if it possesses the character of knitting dress. Aiming at future fashion trend, in this article, we put forward the problems of knitting enterprises in future design and development orientation for knitting dress, and the solution advices for corresponding problems. And the author hopes the article can offer helps for the design of knitting dress and the knitting enterprises.
\end{abstract}

Keywords: Knitting dress, Fashion trend, Enterprise development

The knitting dress possesses important status in the dress domain, and it is one force which can not be ignored in the commodity of dress. From 1980s, people increasingly begin to pay attention to knitting dress which has deserved consumers' favors in the world. The character of making craftwork makes knitting dress possess not only general commonness of dress, but also un-imitable individuality. Many good performances such as comfort, pliability and elasticity make knitting dress form its own special style. Aiming at the status and character presenting in the industrial development of knitting dress design and the problems which should be noticed in the future development process of knitting dress enterprise, in this article, we put forward opinions, hope to reduce the difference with developed countries and promote the further development of China industry of knitting dress.

\section{The characters of design and production for knitting dress}

In the world domain of dress, the development trend from tatting dress to knitting dress occurs. According to the report of International Wool Secretariat Annual Meeting, the knitting dress in the world was increasing by the speed of 5\%-8\% year after year, but the global knitting dress was increasing only by the speed of $2 \%$. The first reason is that the knitting dress is mainly represented by the matching. The matching of knitting dress and tatting dress is easier than the matching of two pieces of tatting dress, because the latitude of size is large and the knitting dress is not limited by the season comparing with tatting dress. Second, as viewed from the technology, the knitting dress such as sweater is fixedly knitted and dyed, and the risk in the slopwork process is easier than the tatting dress. Concretely speaking, the texture of sweater, i.e. the flower pattern, is easier to produce the design of difference. Comparably, it is much easier to weave the sweater with different textures than to develop tatting jacquard fabric with same form. In addition, the design and production of knitting dress can live up to multiple styles and few quantities, and the manufacture speed is quicker than the knitting. So the first order form will have few quantities, and the risk of the market is much lower. According to the character of knitting dress, more market risks are avoided furthest from the design and production of products.

\section{What functions the knitting dress play in the design of suit-dress? What is the development foreground of this} function in future?

The function of knitting dress in future suit-dress still gives priority to assistant matching. For example, the sweater is the common matching in the fashion design. In future, the knitting sweater is still used to match the tatting dress, and because it is easy to operate, so it will become into main fashion. The limitation of sweater character rests with that it is designed as the pattern of frock to match tatting under most situations. Many characters of knitting dress make it develop very extensively, and its development depends on its easy design, manufacture and difference. The dress mainly lies on the difference operation of products, and the tatting is very difficult, but the corresponding matching of knitting and tatting is much easier, and this matching has been a tide. The consumers of knitting dress have extensively adaptive market, the operation is easy, the market has good reaction, and the risk of knitting can be shared in production and 
distribution, so businessmen commend knitting well. Based on the forces of two aspects, this matching tide of knitting and tatting will keep on developing in future.

\section{The future popular tendency of knitting dress}

In recent years, the industry of knitting dress develops quickly. According to the statistic of China National Textile and Apparel Council, the output of knitting dress was about 14.5 billion pieces in 2003, with year on year increase of $15 \%$, and the export increases $27 \%$, and the increase extent fully exceeds the knitting dress. The knitting dress has displayed large development space in domestic and foreign markets, and with complete abolishment of global textile quota, the knitting dress must meet the opportunity with quick development. For example, the proportion of knitting dress and tatting dress in developed countries such as US and Japan has achieved 45:55. In china, the knitting dress is one of important supports of textile industry all along. In ten years, with the increasing quick development trend of knitting dress and the continual extension of knitting dress demand to domestic and foreign markets, the industry of knitting dress in China is in the term of quick development. The market of future knitting dress is large, and the knitting dress would more extensively invade the domain formerly belonging to the tatting dress, and the pattern and the type will be more extensive, but in short time, it will not replace the biggest status of tatting.

\section{Which aspects should be noticed by China enterprises when they study foreign enterprises?}

The present knitting enterprises in China has entered into the mistake overly emphasizing the significance of design. Blindly studying design to foreign enterprises, domestic enterprises even crazily copy foreign designs. In fact, though the significance of design is at the first position, but the knitting dress rests with the development of yarn and the opening of computer-controlled flat knitting machine except for layout and knitting stitch. The development of yarn and the opening of computer-controlled flat knitting machine are needed to be developed first. The reason is that the handmade and machine manufacture mode of tatting dress is different, and the knitting dress is mainly knitted, and because most foreign computer-controlled flat knitting machines are programmed by the computer, so the design and manufacture in foreign enterprises are better than domestic enterprises. For domestic enterprises, the developments of stitch and jacquard are not more important than the developments of yarn and machine. The development of yarn is not a negligible important part, and it is the direction of product difference, because the pattern is easy to be imitated, but the material can not be imitated. The combination of different materials in textile is difficult to develop, but in foreign enterprises, the tatting material has 7 or 8 sorts of material combination for foreign wool spinning material. One design of yarn needs various tests in different aspects, which is more complex than the design of one pattern. So to save costs, many enterprises give up the development of yarn. In fact, it is false, because if the corporation monopolizes the yarn, it will monopolize the profit. The design without the matching of yarn material has not any values. Good matching of design and yarn material can really monopolize the design, and the combination of good design and yarn is flawless, and the use of other yarns can not make this, and the enterprise develops the good variety, it will monopolize the operation and profits. That is the most effective method of anti-pirate in the domain of dress.

As a whole, the industry of knitting dress in China develops well and it is in the period of rapid development. But we can clearly see that the knitting dress of China has large differences with developed countries, and these differences include not only the software difference of concepts such as originality, design and distribution, but also the hardware difference of technologies such as yarn, machine and dying, so the competition of knitting dress is more intense in future. To quicken technical advancement, to adjust product structure, to enhance product added values, to push brand strategy and to completely enhance industrial competitive force are future development directions of knitting dress undoubtedly.

\section{References}

Gui, Jilie. (2001). Design Base of Knitting Dress. Beijing: China Textile \& Apparel Press. January, 2001.

Ma, Dali. (2005). Management of Commodity. Beijing: China Textile \& Apparel Press.

Ma, Dali \& Wang, Xiucai. (2006). The commodity is the king, the commodity management to win the market. Beijing: China Textile \& Apparel Press.

Mao, Lili \& Wang, Xingjia. (2005). The actuality analysis of the Industrial Development for China Knitting Dress. Knitting Industries. No.3.

Shenlei. (2005). Design and Arts of Knitting Dress. Beijing: China Textile \& Apparel Press. January, 2005. 